\title{
Democracy Is Democracy Is Democracy? Changes in Evaluations of International Institutions in Academic Textbooks, 1970-2010
}

\author{
Klaus Dingwerth \\ University St. Gallen \\ Ina Lehmann, Ellen Reichel, and Tobias Weise \\ University of Bremen
}

\begin{abstract}
This article examines what democracy means when it is used in academic textbook evaluations of international institutions and how the meaning of the term "democracy" in such evaluations has changed over time. An analysis of 71 textbooks on international institutions in the policy areas of international security, environmental, and human rights politics leads us to several answers. We observe slight changes in relation to three aspects. First, the range of democracy-relevant actors expands over time, most notably in relation to nonstate actors as important participants in (or even subjects of) international policymaking. Second, representational concerns become more relevant in justifying demands for greater participation in international institutions. Third, international organizations are increasingly discussed not only as subjects that enhance the transparency and accountability of the policies of their member states, but also as the objects of democratic demands for transparency and accountability themselves.
\end{abstract}

Keywords: international institutions, norms, democracy, International Relations textbooks, teaching

\footnotetext{
${ }^{1}$ Klaus Dingwerth is Assistant Professor in Political Theory of Global Governance at the University St. Gallen, Switzerland (email: klaus.dingwerth@unisg.ch); Ina Lehmann, Ellen Reichel, and Tobias Weise are research fellows at the Institute for Intercultural and International Studies, University of Bremen, Germany (email: ina.lehmann@iniis.uni-bremen.de; ellen.reichel@iniis.uni-bremen.de; tobias.weise@iniis.uni-bremen.de). This paper is part of the broader research project "Changing Norms of Global Governance" (www.globalnorms.uni-bremen.de) funded as a part of the Emmy Noether Program of the Deutsche Forschungsgemeinschaft (DFG, Grant No. DI1417/2-1). We gratefully acknowledge the support from the DFG. We also thank Felix Anderl, Marret Bischewski, Benjamin Brast, Nicole Gonyea, Nele Kortendiek, and Helge Staff for their excellent research assistance; Eric Duchesne, Kristina Hahn, Nina Hall, Monika Heupel, Nico Krisch, Bernd Schlipphak, the anonymous reviewers as well as the participants of the "Institutional Dynamics in World Politics: Explaining variation in the scope, pace, and direction of international institutional change" (Wissenschaftszentrum Berlin, Germany, April 7-8, 2011), "Global Governance as Public Authority: Structures, Contestation, and Normative Change" (Hertie School of Governance, Berlin, Germany, April 15-16, 2011), and "Institutional Change in Intergovernmental Organization" (ULB-UGent, Brussels, Belgium, May 27-28, 2011) workshops for comments on earlier versions.

[Corrections added February 5, 2015, after original online publication: grammatical changes have been made to this article to improve clarity.]
}

Dingwerth, Klaus et al. (2015) Democracy Is Democracy Is Democracy? Changes in Evaluations of International Institutions in Academic Textbooks, 1970-2010. International Studies Perspectives, doi: 10.1111/insp.12069

(c) 2014 International Studies Association 
Academic and political discourses are replete with references to fundamental change in international politics. A common narrative holds that, in response to economic globalization, states and nonstate actors have created powerful international institutions, which increasingly face demands for their democratization. From a normative point of view, many authors have argued that in the context of their enhanced authority, international institutions do not only have to fulfill their specific functions, but they need to do so in a-broadly speakingdemocratic manner (Holden 2000; Anderson 2002; Zweifel 2005; Bexell, Tallberg, and Uhlin 2010). Empirically, the argument is that a variety of audiences have factually come to evaluate international institutions in the language of democracy (Zürn 2004). Their demands have been expressed, for instance, in anti-globalization protests against an undemocratic World Trade Organization or in the commitments of individual international institutions - partially in response to public demands - to become more participatory, more transparent, and more accountable (Grigorescu 2007; Tallberg, Sommerer, Squatrito, and Jönsson 2013).

In addition to such evidence for an increasing sensitivity by academics and political actors for issues of global democracy per se, some studies have also recently observed changes in political actors' understanding of democracy and key democratic values. For example, Reimann (2006) shows how, from the early 1990s onwards, the UN has steadily pointed to the democratic potential of partnerships with NGOs instead of being limited to a "one-state-one-vote" understanding of democracy. Similarly, Thérien and Dumontier (2009) find that in recent years the UN has increasingly defended a bottom-up vision of democracy that builds on the participation of private actors. In another study, Mert (2009) shows how the meaning of participation has changed from a more democratic to a more implementation-oriented understanding in Type II partnerships initiated by the 2002 World Summit on Sustainable Development.

Despite the fact that academic debates and publications seem to be more sensitive to the move toward democratic norms in evaluating international institutions than to potential changes in the meaning of (global) democracy, our argument in this article is that this seems to be reversed in conventional academic textbooks over the past four decades. While International Relations (IR) textbooks generally pay only negligible attention to democratic norms, insofar as they do, we can observe various changes with regard to the specific democratic norms they put forward and how they interpret these norms. Thus, our study provides two interesting results: First, in contrast to what one may have expected, textbook references to democracy do not become much more frequent over the course of the past four decades. Second, while the amount of references to democracy remains largely constant, the content of democratic norms shifts over time. When contemporary textbooks refer to democracy, they refer to it in a more diverse way than older textbooks referencing the same term.

We substantiate our claims by an examination of how the meaning of democracy has changed in 71 academic textbooks on international institutions in the areas of international security, environmental, and human rights politics from 1970 to 2010. Our study primarily tells us something about how academic thinking about the democratic legitimacy of international institutions has evolved. ${ }^{2}$ However, by doing so, its results are relevant not only for our understanding of the discipline but also provide one avenue to getting a sense of how the mindsets of decision makers and public officials have changed. Textbook authors

\footnotetext{
${ }^{2}$ In addition, some may argue that academic textbooks are also reflective of other discursive arenas and can therefore be treated as a shortcut to the broader social discourses about international institutions. Yet this claim is more controversial, and we therefore limit our analysis to textbooks as a discursive arena that, for the reasons discussed below, is interesting in itself.
} 
often do not only seek to give a balanced account of the state of the art (Kille 2003:426) - and possibly also the zeitgeist - at the time of their writing. They are also producers of such states of art. "Their texts determine how the field is defined for those who are just beginning to learn about it" (Anonymous 2003:421). Indeed, scholars have variously observed that their teaching has fundamental impacts on the perspectives adopted by their students, who, in the case of political science students, often are future decision makers in various settings (Eriksson and Sundelius 2005:63-65). In the words of former Harvard faculty member and US Secretary of State Henry Kissinger, "the convictions that leaders have formed before reaching high office are the intellectual capital that they will consume as long as they continue in office" (quoted in Eriksson and Sundelius 2005:65). In a quantitative study, Pamela Martin and colleagues show more systematically how political science courses - though not fundamentally challenging students' general attitudes - do contribute to changing political attitudes on single issues (Martin, Tankersley, and Ye 2012:209-212). Thus, textbooks are critical in shaping future knowledge and practice since they-and the value judgments they report or espouse-are part of the intellectual capital that is transmitted to the next generations of scholars and decision makers.

Given that textbook authors should thus carefully consider what information they present and how they present it, it is astonishing how little we know about the values transmitted in IR textbooks. Those few studies that provide a systematic overview of trends in IR teaching are generally concerned with the topics, regions, theories, and methodologies being taught. Yet, they pay only marginal attention to norms and values featured in the classroom (on IR teaching in general, see Jordan, Maliniak, Oakes, Peterson, and Tierney 2009; Peterson, Tierney, and Maliniak 2005; on IR textbooks in particular, see Kille 2003; Smith 2003). Thus, a central contribution of our study is to make scholars aware of how the normative side of what we teach is subject to change. We exemplify this with the help of one particular norm, namely democracy.

The outcomes of our study are that, first, a democratic yardstick is far from a dominant theme in textbook evaluations of international institutions. Second, how textbook authors understand democratic principles changes over time. Most notably, we observe an expansion of the range of legitimacy-relevant actors, a rise in representational concerns that complement functionalist justifications for participation in international institutions, and a growing relevance of international organizations as the objects of transparency and accountability demands. Third, we also find some evidence that evaluations referring to democracy vary across issue areas. They are more relevant in textbooks on international environmental politics than in textbooks on the politics of international human rights and security.

After a brief discussion of our theoretical and methodological approach, we turn to analyzing how democratic norms are referred to in different policy areas and how their meaning changes over time. This empirical analysis unfolds in three steps: We first take a closer look at all those statements in which textbook evaluations of international institutions refer either to democracy itself, or second, to particular democratic values, namely participation, and third, transparency and accountability.

\section{Theory and Methods}

At its very heart, our investigation of the use of democratic norms is concerned with the standards by which international institutions are considered legitimate. We broadly adopt Weber's (1978) notion of legitimacy as the belief in the "rightfulness" of political rule. According to this understanding, an international institution enjoys legitimacy to the extent that it is supported by a "generalized 
perception or assumption" among relevant communities that, in relation to the system of rule to which it belongs, the organization and its activities are "desirable, proper, or appropriate within some socially constructed system of norms, values, beliefs, and definitions" (Suchman 1995:574).

Whereas legitimacy as the belief in the rightfulness of rule is thus first of all a property ascribed to an institution, it can be employed in processes of legitimation through which actors exchange claims and counter-claims on what makes an institution desirable and whether or not it appears as legitimate. In these processes, different actors will try to argumentatively put forward their own notion of legitimacy and thereby push and pull the institutional design and actions of international institutions in one direction or another (Krebs and Jackson 2007). Our guiding question, then, is for which reasons do international institutions come to be seen as acting rightfully? What are the main beliefs that textbooks transmit to those who will be either observers or participants in the process of de/legitimating international institutions - the latter either as contesters of institutions' legitimacy or as staff being responsible for the good conduct of the respective institution? This is where social norms come into play. In our conception, we follow Katzenstein's (1996:5) definition of norms as "collective expectations of proper behavior for actors with a given identity." To put it simply, we conceive of norms as the foundations on which conceptions of legitimacy rely.

Building on this perspective of norms, three theoretical assumptions underlie our argument. First, social norms are consequential. Second, they are negotiated and given expression in the context of social discourses. Third, academic discourse is one discursive arena in which the norms we are interested in become visible, and it is therefore interesting to examine this particular discursive arena.

The first assumption means that it makes a difference whether or not an institution is considered legitimate. On the one hand, legitimacy minimizes the need for forceful implementation of political decisions made by or within an institution since the rule addressees can generally accept the decisions (Reus-Smit 2007). On the other hand, norms can also be consequential in terms of the actors' desire to behave in socially appropriate ways and to be recognized as good members of a specific community. Thus, diplomats and the staff of international institutions have an interest in adhering to international norms (for empirical evidence, for example, Barnett and Finnemore 2004; Weise 2010). The second assumption that norms are negotiated in social discourses means that which norms matter (most) is not determined by some external standard. Rather, different social actors hold different norms. Which norms become dominant or even generally accepted is an outcome of processes in the discursive arena. In this sense, third, academic textbooks are interesting arenas since they are an important medium through which scholars present their particular view on international institutions to the younger generation and thus shape the institutions' image as being more or less legitimate among young academics.

With regard to our specific interest in democratic norms, we conceptually build on Ian Clark's notion of legitimacy norms as embodying elements of rightful membership and rightful conduct (Clark 2005). Accordingly, we analyze changes of the democratic norm from a dual perspective. On the one hand, we examine whether the norm that stipulates who can legitimately make international rules has changed. We ask which interests should be represented in decision making. On the other hand, we ask whether the norm that stipulates how international rules ought to be made in order to count as legitimate has been amended. Here, we inquire which democratic norms are perceived as central for the decision making process (for example, equality, transparency, accountability).

As indicated, we focus on textbooks that discuss international institutions in the areas of international security, human rights, and environmental politics. Our study thus includes policy fields that vary in the level of institutionalization 
of global rule-making. While many of the most important global human rights norms were already codified by the 1970s, environmental politics was a nascent field at that time. As a result, international human rights politics has a stronger focus on the implementation of existing legal norms. In contrast, international environmental politics initially focused on the elaboration of such norms and in more recent decades is characterized by the development of new rules as well as the implementation of existing rules. Finally, security politics was institutionalized early, but only after the end of the Cold War could a number of security institutions, most notably the United Nations, overcome constraints caused by bloc confrontation.

Within these issue areas, we base our selection of academic textbooks on a list of candidate books that we compiled with the help of academic library catalogs and web-based search tools. We narrowed down the list with the help of several criteria: How well do individual books match our definition of academic textbooks? ${ }^{3}$ How often are they cited in other publications? In which languages were they written? Are they available? ${ }^{4}$

While our corpus allows us to identify some interesting trends in the academic discourse of the $1970 \mathrm{~s}$ to $2000 \mathrm{~s}$, it is not representative in a strict sense. The most important sources of potential bias are first the dominance of English language books originating from either the UK or the United States which probably results in a tendency to report Anglo-Saxon rather than global norms. ${ }^{5}$ Second, our preference for more widely used vs. less widely used books possibly results in a tendency to underreport discourses beyond the mainstream literatures. Keeping these limitations in mind, we believe that we can nevertheless say something about how conceptions of democracy in international institutions have changed in textbook discourses.

Methodologically, we apply an interpretative approach. We follow Robert Entman (2004) and others in the assumption that collective and individual perceptions of reality are ordered in frames that provide cognitive patterns to understand the world. For political issues, frames structure the perception of political problems and their possible solutions. Further, we assume that some frames also connect to norms of appropriate behavior. Thus, a typical frame we look for will provide information about norms that guide the evaluation of international institutions themselves, of their activities, and of reform proposals in relation to an institution. Thus, such an ideal-type frame would, for example, praise the United Nations as the true world parliament where all states have equal rights.

In order to identify how the meaning of democratic norms has changed over time, we first coded three kinds of legitimacy statements: (i) evaluative statements that either explicitly or implicitly include normative assessments of an international institution; (ii) proposals for new international institutions that make sufficiently clear what would be "good" about such institutions; and (iii) critiques of proposals for a new international institution. From among this corpus of statements, we only look at those evaluations that make democracy or a particular democratic value their primary standard of evaluation. These statements essentially hold that international institutions are good if they are democratic and that they ought to be reformed if they suffer from a "democratic deficit." To take into account the possibility that the coders for the different issue areas have different levels of sensitivity in either recognizing a statement as

\footnotetext{
${ }^{3}$ According to our definition, textbooks are either explicitly labeled as such by their authors or editors, or (particularly in the 1970 s and 1980s when textbooks were not yet so widespread) they should be labeled or recommended as general introductions to the respective field.

${ }^{4}$ See Appendix 1 for the full list of selected academic textbooks.

${ }^{5}$ The books examined include 51 books written in English, 13 in German and seven in French. Of the books written in English, two-thirds were published in the United States and the rest in the UK.
} 
evaluative or assigning it to the democracy frame, we additionally include all those statements from the initial corpus of legitimacy statements that contain at least one term that might signal a reference to democracy or to a particular democratic value. To keep the analysis manageable, we have restricted our search to the terms democracy, participation, transparency, and accountability (as well as their respective translations for the French and German books included in our analysis). ${ }^{6}$ This choice of terms is motivated by the idea that different conceptions of democratic governance beyond the state overlap in relation to these democratic values (Dingwerth 2007: chapter 2). Having thus identified our corpus of evaluative statements, the main thrust of our argument relies on a fine-grained, qualitative discussion of democracy-related evaluations to which we turn in the following sections.

Before we begin, however, we need to point out that evaluations of international institutions in academic textbooks rely on a plethora of normative frames -including, for example, the functional performance of international institutions, which is their capacity to solve collective problems, or the notion of sovereignty, implying that international institutions should serve as an instrument to protect national autonomy. In contrast, in all issue areas, democracy plays a rather marginal role in the evaluations by textbook authors, and this hardly changes over time. Compared to the issue areas of security and human rights politics, most references to democracy or particular democratic values occur in the issue area of environmental politics. However, even if democracy may not be invoked more frequently in textbooks, given the generally increasing academic attention to the democracy of international institutions, it is still worth looking at this particular norm in more detail, especially as the content of demands related to democracy has changed.

\section{Empirical Analysis: Changing Notions of Democracy}

\section{Explicit References to Democracy}

In our selection of books, only few authors make explicit use of democracy as a standard to evaluate international politics. Those that do are more likely to have written their books in the 1990s and 2000s. Further, they conceive of democracy in rather diverse terms. In addition, there is neither a consensus on the notion that democratic norms ought to apply to international institutions, nor what such a demand would essentially entail. The same applies to the domain to which democracy as a normative standard should be applied. Overall, explicit appeals to democracy come in a variety of ways. We identify two trends. First, international institutions are often ascribed an important role in national democracy promotion. Second, there is a recent demand for democratic procedures in international institutions themselves.

The first trend, the role of international institutions in promoting national democracy, is more common (see Keohane, Macedo, and Moravcsik 2009). This is primarily found in the human rights books and often applied to institutions that make democratic government a requirement for becoming a member state (such as the Council of Europe or, more recently, NATO), or to those whose activities are seen as benefiting the quality of domestic democracy (such as the MERCOSUR, OAS, OECD, OSCE, or the UN). Yet, such references and statements remain rather broad and general.

\footnotetext{
${ }^{6}$ Taking these search terms as a basis may lead to some overlaps as the broader notion of democracy frequently encompasses the other notions. In the empirical analysis below, this comes to the fore when we observe that the notion of democracy as such is tied to understandings of equality or empowerment that also feature in the discussion of the notion of participation. We take this overlap as a sign that such notions gain particular relevance.
} 
The second trend, the direct application of democratic procedures to international organizations, is more nuanced. Only nine of our 71 books apply democracy to international institutions directly. Further, the nine works do not share a coherent understanding of the meaning of democracy and apply the concept to international politics in different ways. Still, we can classify the uses we identified in relation to three particular meanings of democracy: (i) democracy as equality; (ii) democracy as decentralized governance, and (iii) democracy as empowerment.

\section{Democracy as Equality}

First, a number of assessments of individual institutions as either democratic or undemocratic commonly refer to the formal or factual equality among participating states. For instance, a common topic of formal equality is state representation. Here, authors hold that institutions are more democratic when states have equal voting rights than when decision making powers are based on economic power (see Buck 1998:160 on INTERSPUTNIK and INTELSAT). Similarly, the UN General Assembly is described as "the democratic assembly" in opposition to the much smaller and less representative Security Council (Weiss and Kalbacher 2008:334).

Some authors take up the issue of democracy as equality when discussing controversies in international politics. For example, they embed debates on a political post-World War II order and the creation of the UN in this understanding of democracy (see Hurd 2007: chapter 4). To illustrate, Lauren (1998:176) reports that a number of states were unhappy with the proposed UN Charter because of great-power dominance, and he reflects that "if the crusade of World War II was in the name of democratic principles, then surely the new international organization should be based on democracy."

A second controversy is associated with the creation of the Global Environment Facility (GEF) in the first half of the 1990s. The issue is discussed in environmental textbooks (see Brenton 1994; Elliott 1998; Chasek, Downie, and Brown 2006). Here, the authors frame the debates on the setup of the GEF in a democracy language when they, for example, demand "equal representation in the decision making process" (Elliott 1998:200) for developing countries. Here, authors contrast the GEF to the undemocratic World Bank and thus understand it as a tool to democratize global politics.

\section{Democracy as Decentralized Governance}

The centralization and decentralization of governance is an issue that appears with some importance in the environmental politics debates. In the 1970s and 1980s, centralized global rule-making was applauded on a functional basis as a good way to solve global environmental problems (see Falk 1973:150; Kent 1979:246; Harf and Trout 1986:213-214). Yet, this perception changes over time. The more recent textbooks tend to see democratic potential in decentralization. For instance, Elliott (1998:118) argues that, "better governance requires [...] that the practice of global governance be decentralized and democratized" and that it "respond[s] more effectively to local voices and local concerns" (see also O’Neill 2009:6 for a similar argument).

Here, an international governance system is considered democratic to the extent that it does not have a powerful center, but is instead constituted of a plethora of competing or overlapping spheres of authority. Democratizing global governance therefore does not necessarily mean rendering international institutions more participatory, transparent, or accountable, but rather reducing institutions' central authority within the wider governance system through the creation of nontraditional authorities that develop alternative visions and provide space for the contestation of ideas and institutions. 


\section{Democracy as Empowerment}

Some authors argue that international institutions are democratic when they empower their stakeholders to be active political players. For example, Hough (2008:253) criticizes that international institutions often make symbolic use of democratic ideas. They create bodies for stakeholder representation and develop special programs. Yet, the elites that develop these instruments and dominate the institutions do not have sincere intentions to live up to these ideas of true stakeholder empowerment.

A similar conception of democracy as empowerment or emancipation underlies Elliott's (1998:131) discussion of the democratic potential of nonstate actors in global governance. She conceives of global civil society as an "expression of alternative visions of political practice and environmental governance" that emphasize "democratization, participation and the empowerment of marginalized voices, justice and equity and a reclaiming of the local to counter the centralizing tendencies of a reformist, institutionalist approach to global governance." Democracy, in this perspective, is equated with the "effective control of change by those most directly affected" (Elliott 1998:131, citing John Hontelez) and ultimately linked to the idea of emancipation.

\section{Participation of Whom and for What? From Functional to Representational Arguments}

Normative change becomes more visible when we move from references to democracy to references to particular democratic values such as participation, transparency, and accountability. Looking at evaluations that use participation as their normative reference point, two main observations are noteworthy. First, the range of actors that the authors see as relevant expands throughout the decades. Second, justifications for participation in international institutions become broader over time as functionality-based arguments are complemented by concerns about the representative nature of international institutions. Yet, functionality-based participatory demands, that are largely unconnected to participation as a democratic value, are the ones most often used. However, over time, we witness the emergence of an understanding of participation as a means to enhance the representation of various actors and to thereby improve the democratic quality of global policymaking.

\section{The Expansion of Relevant Actors}

As discussed above, textbook authors base parts of their evaluations of international institutions on the adequacy of state participation in international decision making. For most of them, broad participation is important because it enhances the likelihood that transboundary problems will be solved. We find this functional view of participation in many institutional contexts such as the UN General Assembly (Flinterman 1999:146), UN conferences (Strong 1975:262; Juda 1979:91), UN operations (Papp 1984:57), and other treaty negotiations (Goetz Lall 1982:98; Desombre 2002:110). Beyond these functionalist statements, more recent textbooks also discuss the problem of North-South imbalances and their effects on developing state participation. For example, O'Neill (2009:88) discusses the "obstacles to southern participation in global environmental meetings" that result from the strained diplomatic apparatus of Southern countries.

Next to states, there has been a continuous awareness since the 1970 s of the participatory demands of nonstate groups. These are individuals and the general population on the one hand and non-governmental organizations (NGOs) on the other. NGO participation in international affairs is seen as vital in a wide range of textbooks. Yet, especially in the fields of security and human rights, the authors predominantly discuss the important functions fulfilled by NGOs and demand a 
greater role for them in particular international regimes (Schwelb 1978:333; Forsythe 1983:218; Morgan 2006:264). In contrast, in international environmental politics (and to some extent also in the field of human rights politics), nonstate actors are also seen as central to the democratic legitimacy of international decisionmaking processes from the 1980s onwards. Then, the debate about who does and who should participate in global governance gained a clear focus on NGOs, and a more important role for them is demanded (for example, Elliott 1998:101). Also, particular attention is paid to NGOs from the Global South. For example, Kamminga and Rodley (1984:198) report "understandable charges that the NGO community is unrepresentative of the world as a whole" and that "wider participation by NGOs based in the Third World [...] is badly needed." Here, the representational function of NGOs is explicitly addressed and begins to complement the initial focus on functional benefits.

Finally, a major evolution over the past four decades is the much greater attention textbook authors pay to social groups that are traditionally marginalized in international institutions. Most notably, they comprise women's organizations, indigenous groups, and local communities. All these groups are virtually nonexistent in evaluative statements drawn from the textbooks of the 1970s and 1980 s, but are given a prominent role in some textbooks from the 1990s and 2000s (see, for example, Elliott 1998:147-157; Chasek et al. 2006:137; Whitworth 2008:103; Smith 2010:353).

\section{Participation as Representation}

The rise of representational ideas is most evident in relation to evaluative statements that focus on the inclusion of previously marginalized groups. As functional concerns rarely play a role in justifying demands for greater inclusion of these groups, evaluations that refer to them almost exclusively express representational concerns. In other words, they understand representation not as a means, but as a valuable end that international institutions should pursue. The general idea behind representational concerns is expressed in the notion that citizens should have "their say in international fora" (Speth and Haas 2006:136).

This idea gains larger support among textbook authors in the 1990s and 2000s. During that time, NGOs are discussed as delivering information not only to international institutions, but also to a wider public. Thereby, they make critical knowledge available and empower those participating in global governance processes (Elliott 1998:143). Second, this shift in the meaning of participation becomes visible in the increasing use of the deliberation trope in that period. The authors in the human rights and environmental politics areas describe nonstate actors as important interlocutors in international institutions. During deliberations, they make excluded voices heard. As O'Neill (2009:91) puts it, "NGOs have served as the 'conscience-keepers' of the international community" and should therefore push for "wider participation in these deliberations." Furthermore, they broaden the horizons of delegates in deliberations by providing critical perspectives, new ideas, or simply broader views on a given issue (O'Neill 2009:91-92). For instance, Speth and Haas (2006:120) argue that opening the procedures of the WTO to non-trade experts would "[give] the WTO greater legitimacy."

Finally, representational concerns are also visible when the contributions of NGOs or scientists are criticized, either in relation to elites vs. non-elites, or in relation to the representation of societal actors from the Global South. For example, Smith (2010:172) criticizes that in some human rights commissions, "only an elite inner circle of academics, activists, and politicians tends to be aware of the content." In relation to environmental science, some authors "have argued that serious inequities have existed, and often remain, in how Southern 
concerns and experiences are reflected on international scientific agendas" (O'Neill 2009:89). Thus, it is not only the presentation of scientific knowledge that matters, but also the representation of diverse voices in the process of knowledge creation.

\section{The Domain of Transparency and Accountability: From States to International Organizations}

We discuss demands for transparency and accountability together since textbook authors frequently use both ideas in combination and discuss them as closely linked categories. How do textbook authors evaluate international institutions with regard to these values? Two specific observations are noteworthy in this regard. First, there are larger differences between the policy fields we studied. A second observation is that, in the earlier decades, evaluations of international institutions are mainly concerned with international institutions as providers of (national) transparency and accountability. In recent decades, this focus is complemented by demands for the transparency and accountability of international institutions themselves.

First, it is striking that authors of international security textbooks do not discuss transparency as a relevant basis to evaluate the democratic performance of international institutions. Normatively speaking, security is portrayed as a "transparency-free" zone in which openness or publicity is of limited value. This is different in human rights and environmental politics textbooks. In these textbooks, we can identify a broad range of references to transparency, yet often with functional undertones. For instance, the publicity of UN regimes is applauded because it "provides for considerable transparency of the reporting system and allows for monitoring and even lobbying by non-governmental organizations" or because it "contributes to the transparency of process and helps to encourage participation” (Scheinin 1999:433; Smith 2010:170).

Here, the meaning of transparency revolves around ideas of public control, participation, and openness. Transparency is not necessarily seen as a value in itself, but serves to improve monitoring and "to publicize policy failures or successes" (O'Neill 2009:119). Transparency thereby generates information upon which those concerned can act to improve the system. Of course, the textbook corpus also holds a number of contradictory statements that are skeptical of transparency when it conflicts with demands for secrecy in state negotiations and thus reduces the chances of state compromise (for example, Luini Del Russo 1970:85). Yet, those fears of waning confidentiality in international politics decline in the 1990s and later. Rather, authors now criticize possible pitfalls of too much secrecy, like "preventing sufficient public disclosure and discussion" (Lauren 1998:265).

Our second and more important observation is that, apart from states, a number of international institutions are also subjected to demands for transparency and accountability. In contrast to our findings on democracy and participation, some IGOs - most notably the GATT/WTO, the World Bank, and the IMF - are, however, much more the focus of such demands than others. They are criticized when they do not live up to the authors' standards of transparency or accountability, but also praised for their reform efforts to improve their transparency records.

More direct references to accountability-rather than transparency or a combination of both - can be organized along two questions: Who should be accountable? To whom is accountability owed? As with participation, there is also a diversification of the actors that face demands for increased accountability. While a large number of statements - most notably in the domain of human rights - address the legal accountability of states, statements advocating the accountability of international organizations themselves have been growing stronger since the 1990s. For example, Skogly (1999:246) points out that "concern 
over negative human rights impact of the operations of the [World Bank and IMF] themselves, and thus, their accountability in accordance with human rights law" was a relatively new phenomenon.

Concerning the actors to whom accountability is owed, there is a whole series of different actors mentioned. They range from the world community and the citizens of a state to local communities, member states of an international organization, and the stakeholders of international institutions. Interestingly, explicit references to these actors and their differentiation are made almost exclusively in statements from the 1990s. Together with the observation that the concept of liability of international organizations emerges as a theme of discussion around that time, this indicates that the notion of accountability becomes increasingly specified over our period of investigation.

\section{The Changing Role and Meaning of Democracy in IR Textbooks: Conclusions}

Our main research interest in this article was to find out what "democracy" means when it is used in textbook evaluations of international institutions and how the content of democracy-related evaluations has changed over time. An analysis of 71 academic textbooks on international security, environmental, and human rights politics leads us to several answers regarding democracy's relative importance and evolution in meaning. Also, we reflect about the meaning of such changes for IR education.

Numerically, democracy is only one normative standard among others, and it does not seem to become more central in recent decades. This may reflect both mainstream academic discourses and a conservative bias in textbook discourses. Even though, as mentioned in our introduction, a number of IR scholars now turn to analyzing the democratic credentials of international institutions (for example, Zweifel 2005; Grigorescu 2007). Frost's (1996:4) assessment almost two decades ago that IR by and large still avoids normative theorizing retains some validity. More recently, Reus-Smit and Snidal (2008), in their Oxford Handbook of International Relations, have called for a better integration of normative theorizing into empirical (IR) analysis (see also Deitelhoff 2010). To some extent, the lack of attention to democratic norms in textbooks that we identified may thus mirror a general reluctance of IR scholars to openly position themselves normatively. ${ }^{7}$

On the other hand, the more recent moves by at least some IR scholars to take normative reasoning and analysis more seriously make textbooks look like a particularly conservative genre that is relatively slow in taking up new developments within the discipline. While a survey by Peterson, Tierney and Maliniak (2005:1011) has shown that at least outstanding real-world events like the end of the Cold War or the 9/11 terrorist attacks directly motivate a considerable share of (US) scholars to adapt their courses, IR teaching seems to be less adaptive to theoretical developments. Although only few IR scholars still see realism as a fruitful paradigm for their own work, in their introductory courses they continue to emphasize its importance over and over again (Maliniak et al. 2007:11). The widespread neglect of underlying democratic norms and debates in IR textbooks seems thus to fit into a tradition of teaching that focuses on the long-standing canonical contents instead of cutting-edge state of the art developments.

In comparison with other discursive arenas outside academia, textbooks are characterized as having a significant time lag. For instance, a recent analysis of quality newspaper discourses on the UN, the European Union, and the G8 in four different countries claims that roughly one-third of all evaluations in this particular

\footnotetext{
${ }^{7}$ As outlined in the theory and methods section, the dominating orientation toward problem-solving capacity, of course, is also a reflection of underlying norms. Yet, in general, democracy seems to be perceived much more as a contested field and is often viewed as tied much closer to personal convictions.
} 
discursive arena relate to democratic norms (Nullmeier et al. 2010). The relevance of democratic yardsticks thus seems considerably higher in media discourses than in textbook discourses. Overall, the (numerical) lack of attention to democracy in IR textbooks calls on us as scholars not only to take the normative foundations of our discipline more seriously but also to better bring in line "what we preach (research) with what we teach (pedagogy in the classroom)" (Peterson, Tierney and Maliniak 2005:3).

Qualitatively, however, focusing exclusively on the democracy-related statements within our text corpus, we make some interesting observations with regard to discourses on the legitimation and legitimacy of international institutions. Notably, we observe normative changes in relation to three aspects that speak to both dimensions of legitimacy identified by Clark (2005), namely the dimensions of rightful actors and rightful conduct. First, in relation to Clark's first dimension, the range of legitimacy-relevant actors expands over time, most markedly in relation to nonstate actors and marginalized groups as legitimate participants in (or even subjects of) international policymaking. Second, and linked to notions of both rightful actors and rightful conduct, representational concerns become more relevant in justifying demands for greater participation in international institutions. Third, and more directly connected to ideas about rightful conduct, at least in the environmental policy and human rights fields, international organizations increasingly become the objects of demands for transparency and accountability, both in terms of who should be accountable and to whom accountability is owed.

More broadly, the qualitative discussion in relation to participation, transparency, and accountability shows that democratic norms are becoming more encompassing. Thus, international organizations are now expected to be representative of a much greater variety of state and nonstate actors; they are expected not only to contribute to the transparency and accountability of states and interstate relations, but to also be transparent and accountable themselves. Overall, this expansion adds complexity to the normative field in which international organizations operate and increases challenges to their legitimacy.

Interestingly, despite the overall conservative bias in the form of a strong reluctance to take up normative questions in standard IR textbooks at all, it seems that when authors do take a position, they are much more sensitive to the variety of meanings that the concept of democracy can take and thereby firmly reflect current political and academic developments and discourses. The trend toward emphasizing more participation by a broader audience of stakeholders is hence very much in line with recent political and academic discourses regarding the politicization of international institutions (for example, Zürn, Binder, and Ecker-Ehrhardt 2012). Thus, to the extent that students are confronted with questions of democracy in IR textbooks, what they are taught by and large seems to be in line with the zeitgeist. If we assume (as we do) that norms are negotiated and that one space where they can be pushed very strongly are textbooks as (especially for younger students) textbooks have the aura of being authoritative, then we can conclude that one message students now learn more than two or three decades ago is that democratic values apply to and can be demanded of a wide range of international actors.

Drawing on these findings, we suggest two routes for further research, the first one being more empirical and the second one more conceptual. First, so far we have taken a broad and general view on a variety of textbooks without systematically differentiating between the policy fields. However, at some points, it became clear that there might be differences in how democracy is treated in textbooks for different policy areas. For example, in contrast to environmental and human rights politics textbooks, we found that security politics textbooks hardly pay attention to transparency of international institutions. Most notably, in contrast to environmental politics books, security politics books also did not 
move from a functional to a representational understanding of NGO participation. To further analyze, this might provide additional relevant insights. Do students that opt for international security politics courses get another idea of global democracy than students who opt for international human rights or environmental politics?

Second, in terms of the sociology of the discipline and the teaching of IR, it would be illuminating to systematically study which criteria scholars have in mind when writing textbooks and particularly which normative orientations they want to bring across. In particular, it might be telling to reflect how IR textbook authors, on the one hand, frequently shy away from openly making democracyrelated statements, but on the other hand, through the back door, their changed mind-sets in terms of which precise democratic values they endorse obviously do inform them when writing textbooks. In this sense, then, textbooks appear slightly less conservative than the mere numbers of democracy-related statements suggest, but they are instead influenced by the (normative) zeitgeist. Therefore, even though we find only minimal change in the overall importance of democracy in textbooks, the finding that there have been a number of changes in the perception of the democratic norm and how it is presented is highly relevant.

\section{References}

Anderson, James, Ed. (2002) Transnational Democracy: Political Spaces and Border Crossings. London: Routledge.

Anonymous. (2003) Editor's Note: How Do Textbooks Represent the Field of International Studies? International Studies Review 5 (1): 421.

Barnett, Michael, and Martha Finnemore. (2004) Rules for the World: International Organizations in Global Politics. Ithaca: Cornell University Press.

Bexell, Magdalena, Jonas Tallberg, and Anders Uhlin. (2010) Democracy in Global Governance: The Promises and Pitfalls of Transnational Actors. Global Governance 16 (1): 81-101.

Brenton, Tony. (1994) The Greening of Machiavelli: The Evolution of International Environmental Politics. London: Royal Institute of International Affairs.

Buck, Susan J. (1998) The Global Commons: An Introduction. New York: Island Press.

Chasek, Pamela, David L. Downie, and Janet Welsh Brown. (2006) Global Environmental Politics. Boulder: Westview Press.

CLARK, IAn. (2005) Legitimacy in International Society. Oxford: Oxford University Press.

Deitelhoff, Nicole. (2010) Parallele Universen Oder Verschmelzung der Horizonte? Zeitschrift für Internationale Beziehungen 17 (2): 279-292.

Desombre, Elizabeth. (2002) The Global Environment and World Politics. London: Continuum.

Dingwerth, Klaus. (2007) The New Transnationalism: Transnational Governance and Democratic Legitimacy. Basingstoke: Palgrave Macmillan.

Elliott, Lorraine. (1998) The Global Politics of the Environment. Basingstoke: Macmillan.

Entman, Robert M. (2004) Projections of Power: Framing News, Public Opinion, and U.S. Foreign Policy. Chicago: University of Chicago Press.

Eriksson, Johan, and Bengt Sundelius. (2005) Molding Minds That Form Policy: How to Make Research Useful. International Studies Perspectives 6 (1): 51-71.

Falk, Richard A. (1973) Environmental Policy as a World Order Problem. In Environmental Policy: Concepts and International Implications, edited by Albert Utton and Daniel H. Henning. New York: Praeger.

Flinterman, Cees. (1999) Extra-Conventional Standard-Setting and Implementation in the Field of Human Rights. In An Introduction to the International Protection of Human Rights: A Textbook, edited by Raja Hanski and Markku Suksi. Turku: Abo Akademi University.

Forsythe, DAvid. (1983) Human Rights and World Politics. Lincoln: University of Nebraska Press.

Frost, Mervyn. (1996) Ethics in International Affairs: A Constitutive Theory. Cambridge: Cambridge University Press.

Goetz Lall, Betty. (1982) Disarmament and International Security. In Alternative Methods for International Security, edited by Carolyn Stephenson. Washington, DC: University Press of America. 
Grigorescu, Alexandru. (2007) Transparency of Intergovernmental Organizations: The Roles of Member-States, International Bureaucracies, and Non-Governmental Organizations. International Studies Quarterly 51 (3): 625-648.

Harf, James, and B. Thomas Trout. (1986) The Politics of Global Resources: Population, Food, Energy, and Environment. Durham: Duke University Press.

Holden, Barry, Ed. (2000) Global Democracy: Key Debates. London: Routledge.

Hough, Peter. (2008) Understanding Global Security. London: Routledge.

Hurd, IAn. (2007) After Anarchy: Legitimacy and Power in the United Nations Security Council. Princeton: Princeton University Press.

Jordan, Richard, Daniel Maliniak, Amy Oakes, Susan Peterson, and Michael J. Tierney. (2009) One Discipline or Many? TRIP Survey of International Relations Faculty in Ten Countries. Teaching, Research, and International Policy (TRIP) Project, The Institute for the Theory and Practice of International Relations, The College of William and Mary. Available at http://www.wm.edu/ offices/itpir/_documents/trip/final_trip_report_2009.pdf (Accessed June 12, 2013).

Juda, Lawrence. (1979) International Environmental Concern: Perspectives of and Implications for Developing States. In The Global Predicament: Ecological Perspectives on World Order, edited by David Orr and Marvin S. Soroos. Chapel Hill: University of North Carolina Press.

Kamminga, Menno, and Nigel S. Rodley. (1984) Direct Intervention at the UN: NGO Participation in the Commission on Human Rights and Its Sub-Commission. In Guide to International Human Rights Practice, edited by Hurst Hannum. Philadelphia: University of Pennsylvania Press.

Katzenstein, Peter J. (1996) Introduction: Alternative Perspectives on National Security. In The Culture of National Security: Norms and Identity in World Politics, edited by Peter J. Katzenstein. New York: Columbia University Press.

Kent, George. (1979) Global Fisheries Management. In The Global Predicament: Ecological Perspectives on World Order, edited by David Orr and Marvin S. Soroos. Chapel Hill: University of North Carolina Press.

Keohane, Robert O., Stephen Macedo, and Andrew Moravcsik. (2009) Democracy-Enhancing Multilateralism. International Organization 63 (1): 1-31.

Kille, Kent J. (2003) International Organization: What Do We Know and How Do We Pass on Our Knowledge? International Studies Perspectives 5 (3): 426-433.

Krebs, Ronald K., and Patrick T. Jackson. (2007) Twisting Tongues and Twisting Arms: The Power of Political Rhetoric. European Journal of International Relations 13 (1): 35-66.

Lauren, Paul. (1998) The Evolution of International Human Rights: Visions Seen. Philadelphia: University of Pennsylvania Press.

Luini Del Russo, Alessandra. (1970) International Protection of Human Rights. Washington, DC: Lerner Law Book Co.

Maliniak, Daniel, Amy Oakes, Susan Peterson, and Michael J. Tierney. (2007) The International Relations Discipline, 1980-2006. Paper for the Annual Meeting of the American Political Science Association, Chicago, IL, August/September 2007. Available at http://www.wm.edu/ offices/itpir/_documents/trip/the_international_relations_discipline_2007.pdf (Accessed June 12, 2013).

Martin, Pamela, Holley Tankersley, and Min Ye. (2012) Are They Living What They Learn? Assessing Knowledge and Attitude Change in Introductory Politics Courses. Journal of Political Science Education 8 (2): 201-223.

Mert, Ayşem. (2009) Partnerships for Sustainable Development as Discursive Practice: Shifts in Discourses of Environment and Democracy. Forest Policy and Economics 11: 326-339.

Morgan, Patrick M. (2006) International Security: Problems and Solutions. Washington, DC: CQ Press.

Nullmeier, Frank, Dominika Biegon, Jennifer Gronau, Martin Nonhoff, Henning Schmidtke, and Steffen SCHNEIDER. (2010) Prekäre Legitimitäten: Rechtfertigung von Herrschaft in der Postnationalen Konstellation. Frankfurt: Campus.

O’Neill, Kate. (2009) The Environment and International Relations. Cambridge: Cambridge University Press.

Papp, Daniel. (1984) Contemporary International Relations: Frameworks for Understanding. New York: Macmillan.

Peterson, Susan, Michael J. Tierney, and Daniel Maliniak. (2005) Teaching and Research Practices, Views on the Discipline, and Policy Attitudes of International Relations Faculty at U.S. Colleges and Universities. Teaching, Research and International Policy Project, The College of William and Mary. Available at http://www.wm.edu/offices/itpir/_documents/trip/trip_summary2005. pdf (Accessed June 12, 2012). 
Reimann, Kim D. (2006) A View From the Top: International Politics, Norms and the Worldwide Growth of NGOs. International Studies Quarterly 50 (1): 45-68.

Reus-Smit, Christian. (2007) International Crises of Legitimacy. International Politics 44 (2): 157-174.

Reus-Smit, Christian, and Duncan Snidal, Eds. (2008) The Oxford Handbook of International Relations. Oxford: Oxford University Press.

Scheinin, Martin. (1999) International Mechanisms and Procedures for Implementation. In An Introduction to the International Protection of Human Rights: A Textbook, edited by Raija Hanski and Markku Suksi. Turku: Abo Akademi University.

Schwelb, Egon. (1978) Procédures Suivies et Mesures Prises par les Organs de L'ONU Dans le Domaine des Droits de L'homme. In Les Dimensions Internationales des Droits de L'Homme: Manuel Destiné a L'Enseignement des Droits de L'Homme Dans les Universités, edited by Karl Vasak. Paris: UNESCO.

Skogly, Sigrun I. (1999) The Position of the World Bank and the International Monetary Fund in the Human Rights Field. In An Introduction to the International Protection of Human Rights: A Textbook, edited by Raija Hanski and Markku Suksi. Turku: Åbo Akademi University.

Smith, Courtney B. (2003) Learning About International Relations in a Changing World. International Studies Perspectives 5 (3): 421-426.

Smith, Rhona. (2010) Textbook on International Human Rights. Oxford: Oxford University Press.

Speth, James, and Peter HaAs. (2006) Global Environmental Governance. New York: Island Press.

Strong, Maurice. (1975) An Ecological Approach to Management. In Politics and Environment: A Reader in Ecological Crisis, edited by Walt Anderson. Pacific Palisades, CA: Goodyear.

Suchman, Mark C. (1995) Managing Legitimacy: Strategic and Institutional Approaches. The Academy of Management Review 20: 571-610.

Tallberg, Jonas, Thomas Sommerer, Theresa Squatrito, and Christer Jönsson. (2013) The Opening Up of International Organizations: Transnational Access in Global Governance. Cambridge: Cambridge University Press.

Thérien, Jean-Philippe, and Madeleine Bélanger Dumontier. (2009) The United Nations and Global Democracy: From Discourse to Deeds. Cooperation and Conflict 44 (4): 355-377.

Weber, Max. (1978) Economy and Society. Berkeley: University of California Press.

Weise, Tobias. (2010) Du Kommst Hier (Nicht) Rein! Wie Staatenvertreter als Türsteher in Fragen der Öffnung Internationaler Regierungsorganisationen mit Konkurrierenden Normen Argumentieren. M.A. dissertation, Freie Universität Berlin, Humboldt-Universität zu Berlin and Universität Potsdam.

Weiss, Thomas G., and Danielle Zach Kalbacher. (2008) The United Nations. In Security Studies: An Introduction, edited by Paul D. Williams. London: Routledge.

Whitworth, Sandra. (2008) Feminist Perspectives. In Security Studies: An Introduction, edited by Paul D. Williams. London: Routledge.

Zürn, Michael. (2004) Global Governance and Legitimacy Problems. Government and Opposition 39 (2): 260-287.

Zürn, Michael, Martin Binder, and Matthias Ecker-Ehrhardt. (2012) International Authority and Its Politicization. International Theory 4 (1): 69-106.

Zweifel, Thomas. (2005) International Organizations and Democracy: Accountability, Politics, and Power. New York: Lynne Rienner.

\section{Appendix 1}

\section{List of Textbooks Included in This Study}

\section{A. International Environmental Politics}

Anderson, Walt. (1975) Politics and Environment: A Reader in Ecological Crisis. Pacific Palisades, CA: Goodyear.

Barde, Jean-Philippe. (1992) Economie et Politique de L'environnement. Paris: Presses universitaires de France.

Brenton, Tony. (1994) The Greening of Machiavelli: The Evolution of International Environmental Politics. London: Royal Institute of International Affairs.

Buck, Susan J. (1998) The Global Commons: An Introduction. Washington, DC: Island Press.

Caldwell, Lynton K. (1984) International Environmental Policy. Emergence and Dimensions. Durham, NC: Duke University Press. 
Chasek, Pamela, David L. Downie, and Janet Welsh Brown. (2006) Global Environmental Politics. Boulder: Westview Press.

Dahlberg, Kenneth. (1985) Environment and the Global Arena: Actors, Values, Policies, and Futures. Durham, NC: Duke University Press.

Desombre, Elizabeth. (2002) The Global Environment and World Politics. London: Continuum.

Doran, Charles F., Manfred O. Hinz, and Peter C. Mayer-Tasch. (1974) Umweltschutz, Politik des Peripheren Eingriffs: Eine Einführung in die Politische Ökologie. Neuwied: Luchterhand.

Dryzek, John. (1987) Rational Ecology: Environment and Political Economy. New York: Basil Blackwell.

Ehrlich, Paul. (1972) Population, Resources, Environment Issues in Human Ecology. San Francisco: W.H. Freeman.

Elliott, Lorraine M. (1998) The Global Politics of the Environment. Basingstoke: Macmillan.

Glaeser, Bernhard. (1989) Umweltpolitik Zwischen Reparatur und Vorbeugung: Eine Einführung am Beispiel Bundesrepublik im Internationalen Kontext. Opladen: Westdeutscher Verlag.

Harf, James, and B. Thomas Trout. (1986) The Politics of Global Resources: Population, Food, Energy, and Environment. Durham, NC: Duke University Press.

Jänicke, Martin, and Michael Stitzel. (2003) Lern- und Arbeitsbuch Umweltpolitik: Politik, Recht und Management des Umweltschutzes in Staat und Unternehmen. Bonn: Verlag J. H. W. Dietz.

Lipschutz, Ronnie. (2004) Global Environmental Politics: Power, Perspectives, and Practice. Washington, DC: CQ Press.

O’Neill, Kate. (2009) The Environment and International Relations. Cambridge: Cambridge University Press.

Orr, David, and Marvin S. Soroos. (1979) The Global Predicament: Ecological Perspectives on World Order. Chapel Hill: University of North Carolina Press.

PArk, Chris. (1986) Environmental Policies: An International Review. Kent: Croom Helm.

Pirages, Dennis. (1978) The New Context for International Relations: Global Ecopolitics. Pacific Grove, CA: Duxbury Press.

Porter, Gareth, and Janet Welsh Brown. (1991) Global Environmental Politics. Boulder: Westview Press.

Simonis, Udo. (1996) Weltumweltpolitik: Grundriß und Bausteine Eines Neuen Politikfeldes. Berlin: Ed. Sigma.

Speth, James, and Peter HaAs. (2006) Global Environmental Governance. Washington, DC: Island Press.

Sprout, Harold H., and Margaret T. Sprout. (1971) Toward a Politics of the Planet Earth. New York: Van Nostrand Reinhold Co.

Utton, Albert, and Daniel H. Henning. (1973) Environmental Policy. Concepts and International Implications. New York: Praeger.

Valantin, Jean-Michel. (2007) Écologie et Gouvernance Mondiale. Paris: Autrement.

\section{B. International Human Rights Politics}

Brownlie, Ian. (1979) Principles of Public International Law. Oxford: Oxford University Press.

Buergenthal, Thomas. (1995) International Human Rights in a Nutshell. St. Paul, MN: West Publishing.

Claude, Richard. (1989) Human Rights in the World Community: Issues and Action. Philadelphia: University of Pennsylvania Press.

Donnelly, Jack. (1993) International Human Rights. Boulder: Westview Press.

Ermacora, Felix. (1974) Menschenrechte in der sich Wandelnden Welt. Wien: Verl. d. Österr. Akad. d. Wiss.

Forsythe, DAvid. (1983) Human Rights and World Politics. Lincoln: University of Nebraska Press.

Forsythe, David. (2008) Human Rights in International Relations. Cambridge: Cambridge University Press.

Fritzsche, KarL. (2009) Menschenrechte Eine Einführung mit Dokumenten. Paderborn: Schöningh.

Hamm, BrigitTe. (2003) Menschenrechte: Ein Grundlagenbuch. Opladen: Leske + Budrich.

Hannum, Hurst. (1984) Guide to International Human Rights Practice. Philadelphia: University of Pennsylvania Press.

Hanski, Rajja, and Markku Suksi. (1999) An Introduction to the International Protection of Human Rights: A Textbook. Turku: Institute for Human Rights, Abo Akademi University.

Kimminich, Отто. (1975) Einführung in das Völkerrecht. Pullach: Verlag Dokumentation.

Lauren, Paul. (1998) The Evolution of International Human Rights: Visions Seen. Philadelphia: University of Pennsylvania Press.

Luini Del Russo, Alessandra. (1970) International Protection of Human Rights. Washington, DC: Lerner Law Book. 
Newman, Frank. (1990) International Human Rights: Law, Policy, and Process. Cincinnati, OH: Anderson Pub. Co.

Robertson, Arthur Henry. (1982) Human Rights in the World: An Introduction to the Study of the International Protection of Human Rights. New York: St. Martin's Press.

Schilling, Theodor. (2010) Internationaler Menschenrechtsschutz das Recht der EMRK und des IPbpR. Tübingen: Mohr Siebeck.

Sieghart, Paul. (1983) The International Law of Human Rights. Cambridge: Clarendon Press.

Smith, Rhona. (2010) Textbook on International Human Rights. Oxford: Oxford University Press.

VASAK, Karel. (1978) Les Dimensions Internationales des Droits de L'homme: Manuel Destiné à L'enseignement des Droits de L'homme Dans les Universités. Paris: UNESCO.

\section{International Security Politics}

Chan, Steve. (1984) International Relations in Perspective: The Pursuit of Security, Welfare, and Justice. Basingstoke: Macmillan.

Chauprade, Aymeric. (1999) Dictionnaire de Géopolitique: États, Concepts, Auteurs. Paris: Ellipses.

Colard, Daniel. (1977) Les Relations Internationales. Paris: Masson.

Colard, Daniel, and Jean-Francois Guilhaudis. (1987) Le Droit de la Sécurité Internationale. Paris: Masson.

Dinstein, Yoram. (1994) War, Aggression, and Self-Defence. Cambridge: Grotius.

Fierke, Karin. (2007) Critical Approaches to International Security. Cambridge: Polity.

Groom, A. J. R., and Margot Ligh. (1994) Contemporary International Relations: A Guide to Theory. London: Pinter Publishers.

Hopkins, Raymond F. (1973) Structure and Process in International Politics. New York: Harper \& Row.

Hough, Peter. (2008) Understanding Global Security. London: Routledge.

Hütter, JoAchim. (1976) Einführung in die Internationale Politik. Stuttgart: Kohlhammer.

Knapp, Manfred, and Lothar Brock. (1990) Einführung in die Internationale Politik: Studienbuch. Munich: Oldenbourg.

Krell, GeRT. (2004) Weltbilder und Weltordnung: Einführung in die Theorie der Internationalen Beziehungen. Baden-Baden: Nomos.

Laroche, Josepha. (1998) Politique Internationale. Paris: LGDJ.

List, Martin, Maria Behrens, Wolfgang Reichardt, and Georg Simonis. (1995) Internationale Politik: Probleme und Grundbegriffe. Opladen: Leske + Budrich.

Morgan, Patrick M. (2006) International Security: Problems and Solutions. Washington, DC: CQ Press.

PaPp, Daniel. (1984) Contemporary International Relations: Frameworks for Understanding. Basingstoke: Macmillan.

Reynolds, Philip Alan. (1971) An Introduction to International Relations. London: Longman.

Rourke, John. (1986) International Politics on the World Stage. Monterey: Brooks/Cole.

Russett, Bruce. (1985) World Politics: The Menu for Choice. New York: Freeman.

Stephenson, Carolyn. (1982) Alternative Methods for International Security. Washington, DC: University Press of America.

Sullivan, Michael. (1976) International Relations: Theories and Evidence. Toronto: Prentice Hall.

Tickner, J. Ann. (1992) Gender in International Relations: Feminist Perspectives on Achieving Global Security. New York: Columbia University Press.

Viotti, Paul R., and Mark V. Kauppi. (1997) International Relations and World Politics: Security, Economy, Identity. Toronto: Prentice Hall.

Williams, Paul D., Ed. (2008) Security Studies: An Introduction. London: Routledge.

Ziegler, David. (1977) War, Peace and International Politics. Boston: Little, Brown and Company. 